\title{
Identifying potentially harmful jellyfish blooms using shoreline surveys
}

\author{
Nicholas E. C. Fleming ${ }^{1,2}$, Chris Harrod ${ }^{1,3,4}$, Jonathan D. R. Houghton ${ }^{1,2, *}$ \\ ${ }^{1}$ School of Biological Sciences, Queen's University Belfast, Medical Biology Centre, 97 Lisburn Road, Belfast BT9 7BL, UK \\ ${ }^{2}$ Queen's University Belfast Marine Laboratory, 12-13 The Strand, Portaferry BT22 1PF, UK \\ ${ }^{3}$ School of Biological and Chemical Sciences, Queen Mary University of London, Mile End Road, London E1 4NS, UK \\ ${ }^{4}$ Instituto de Ciencias Naturales Alexander Von Humboldt, Universidad de Antofagasta, Avenida Angamos 601, \\ Antofagasta, Chile
}

\begin{abstract}
Interactions between jellyfish and aquaculture operations are frequent around the world, with scyphozoan (in particular Pelagia noctiluca) and hydrozoan species documented as causative agents in major fish kills. Identifying areas of major aggregations or incursions of particular species around a coastline is a good starting point when assessing the threat of jellyfish blooms to existing or potential aquaculture facilities. Here we tested the viability of shoreline surveys to identify areas at risk from coastal and/or oceanic jellyfish species. Surveys were undertaken at over 40 sites around the north of Ireland (covering $\sim 1800 \mathrm{~km}$ of coastline) from 2009 to 2011 to test 2 specific hypotheses: (1) strandings of coastal jellyfish species with life cycles involving production of medusae from benthic polyps or hydroids would display a marked spatial consistency over time, although the magnitude of events may vary inter-annually; and (2) incursions of oceanic jellyfish species (lacking polyps) would impact large areas of coastline and be more episodic in nature. Seven jellyfish species known to harm farmed finfish displayed spatially consistent stranding distributions, with major stranding events evident at several locations. More generally, coastal species stranded throughout the study area at the end of summer, whilst oceanic species were found along the exposed north shore of Ireland, washing ashore during the autumn/winter. The numbers of individuals within stranding events were greater for oceanic species (e.g. P. noctiluca, mean \pm SE $=1801 \pm 978$ ind. $\mathrm{km}^{-1}$ ) than coastal species (e.g. Aurelia aurita $=112 \pm 51$ ind. $\mathrm{km}^{-1}$ ), supporting the idea that large offshore aggregations of $P$. noctiluca remain a threat to the aquaculture industry across the region.
\end{abstract}

KEY WORDS: Scyphozoan · Hydrozoan $\cdot$ Gelatinous zooplankton $\cdot$ Community composition $\cdot$ Pelagia noctiluca $\cdot$ Ireland

\section{INTRODUCTION}

Jellyfish blooms are a known threat to coastal industries (e.g. aquaculture on-growing facilities, recreational beaches and power stations), yet our ability to predict or even quantify the threat remains an on-going challenge (Nickell et al. 2010). To date, many studies of such aggregations have focused on areas dominated by those jellyfish (i.e. Phylum Cnidaria, Class Scyphozoa) with a metagenic life history comprising an alternation of free-swimming and sexually reproducing medusae with asexually bud-

${ }^{*}$ Corresponding author. Email: j.houghton@qub.ac.uk ding benthic polyps (Arai 1997). As the polyps can persist over many years (Lucas 2001, Purcell et al. 2009, Lucas et al. 2012), it is logical to suggest some degree of spatial consistency in the resultant jellyfish aggregations from year to year, although long-term data to test this idea are relatively scarce (Colin \& Kremer 2002, Condon et al. 2012, 2013).

A notable exception to this conjecture is the scyphomedusan Pelagia noctiluca (Forsskål 1775), which lacks a near-shore polyp stage and can form large aggregations in offshore areas (Russell 1967, Purcell 2005, Ferraris et al. 2012). Periodic and highly prob-

() The authors 2013. Open Access under Creative Commons by Attribution Licence. Use, distribution and reproduction are unrestricted. Authors and original publication must be credited. 
lematic incursions of $P$. noctiluca are well documented in the Mediterranean Sea (Rottini-Sandrini et al. 1980, Zavodnik 1987, CIESM 2001), yet the species had received little attention in the North East Atlantic (NEA) until recently (Doyle et al. 2008, Licandro et al. 2010). Most notable were the extraordinary abundances recorded around the north of Ireland in November 2007 (spanning more than $4^{\circ}$ of latitude along a $1500 \mathrm{~km}$ cruise track) that ultimately caused damage worth over $£ 1$ million to the Northern Irish aquaculture industry in a matter of days (Doyle et al. 2008). This species was also a suspected causative agent of over 1 million Atlantic salmon Salmo salar killed off northwest Ireland in 2003 (Cronin et al. 2004), and aquaculture companies still express grave concern over this ongoing threat (Nickell et al. 2010). Moreover, as the drivers of oceanic jellyfish incursions in the NEA are poorly understood (Doyle et al. 2008), insurance companies have, in the past, had no other option than to classify such events as 'acts of God', with subsequent marked negative economic impacts for the marine aquaculture sector.

Such high-profile case studies of jellyfish-induced fish kills (see review by Rodger et al. 2011 for examples) can sometimes lead to the perception that jellyfish represent a recent or rapidly increasing threat to the industry. For example, the events of 2007 were reported throughout the international media as unprecedented and indicative of a regime shift within the NEA, yet these claims were purely speculative. Indeed, a follow-up study by Doyle et al. (2008) revealed that such incursions of oceanic jellyfish into UK/Irish waters were far from rare, with Pelagia noctiluca reported anecdotally in 21 out of a possible 95 years between 1890 and 1985. This assertion was supported further by Licandro et al. (2010) and Bastian et al. (2011), who revealed that major aggregations of this species can frequently occur between the Bay of Biscay and the north of Scotland.

Effective threat assessment of jellyfish blooms requires data to be gathered over a number of years in a cost effective manner that can be easily replicated at different locations. In terms of mapping the distribution of jellyfish, a number of potential methods are available. The UK Crown Estate recently commissioned a study in response to the Scottish salmon mariculture industry's concerns about mortalities related to jellyfish blooms (Nickell et al. 2010). This project aimed to develop the capacity to monitor the spatial and temporal distributions of jellyfish in western Scottish waters. Several techniques were successfully tested, ranging from reporting networks at fish farms through to coastal aerial surveys and satel- lite remote sensing. Each method, in turn, was described, stating advantages and disadvantages (also see review by Purcell 2009), and with clear recommendations for the future including: (1) the development of a reporting network, (2) the set-up of sentinel water monitoring sites and (3) continued trials with new and emerging techniques such as the advanced molecular identification of jellyfish in continuous plankton recorder tows.

One of the key considerations, however, when seeking to establish a long-term monitoring protocol is financial outlay (e.g. aircraft, ship time) or the requirement for specialised equipment and training. Within this context, an additional method that shows promise is the monitoring of jellyfish strandings along the shoreline, which has been used previously to identify the broad-scale distribution patterns (Doyle et al. 2007) and reproductive seasonality (Houghton et al. 2007) of jellyfish medusae. Naturally, this method comes with its own caveats, as strandings data do not indicate the duration that a species is present in the water column in a particular area, nor do they take into account those species which are very small, fragile and quick to decompose (e.g. ctenophores and small hydromedusae). Such species are more readily identified by in situ monitoring at aquaculture facilities (see Baxter et al. 2011a). Here, the focus is on the broad-scale distribution of larger scyphozoan jellyfish which have proved problematic in Irish/UK waters over recent years. Strandings, in the main, reflect the end of season fall-out which retrospectively provides an indication of what species 'were' present in an area in a given year as well as inter-annual variation in the magnitude of blooms. Although of limited direct utility in the short term, such data when viewed over consecutive years provide invaluable information regarding the location and persistence of threats. Amongst ecologists, this method is gaining recognition, as highlighted by the recent National Centre for Ecological Analysis and Synthesis jellyfish working group which incorporated such data into a global synthesis of reports of jellyfish abundance (e.g. Condon et al. 2012, 2013).

To assess the efficacy of shoreline surveys from a coastal stakeholder perspective including aquaculture, the Northern Ireland Government funded a programme in 2007 (prompted by the County Antrim fish kill) to record jellyfish strandings around the north of Ireland $(>1800 \mathrm{~km}$ of coastline between Counties Donegal in the west and Down in the east). More than 500 surveys were conducted across 40 sites (2009 to 2011), with data gathered for an assemblage of scyphozoan and hydrozoan jellyfish (i.e. 
documented threats to aquaculture on-growing facilities; Rodger et al. 2011). Here we report the findings of this programme and highlight a method that has broad applicability to the expanding aquaculture sector in UK/Irish waters (FAO 2012). More specifically, we were interested in the utility of strandings data to provide a broad spatial backdrop for potential threats facing aquaculture facilities brought about through incursions of oceanic jellyfish (Doyle et al. 2008) and long-standing aggregations of coastal jellyfish (Houghton et al. 2007, Lee et al. 2013). From a biological perspective, we hypothesised that: (1) the stranding of coastal jellyfish species with life cycles involving strobilation/budding off of ephyrae (i.e. the precursor to medusae) from benthic polyps or hydroids would display a marked spatial consistency over time, although the magnitude of events may vary inter-annually, and (2) incursions of oceanic jellyfish species (lacking polyps) would impact large areas of the coastline exposed to the open Atlantic and would be more episodic in nature.

\section{MATERIALS AND METHODS}

\section{Shoreline survey area and design}

Jellyfish stranding data were collected from the north of Ireland (Counties Down to Donegal) as part of a systematic beach survey programme from July 2009 to August 2011 (40 beaches, >580 individual surveys covering $\sim 1800 \mathrm{~km}$ of coastline; Fig. 1) following methods outlined by Houghton et al. (2007) and Doyle et al. (2007). All survey sites constituted sandy beaches to avoid medusae being broken up or overlooked during surveys. The coastline was then divided into 4 zones, each consisting of 10 beaches which were classified according to their proximate body of water: Zone 1, Irish Sea; Zone 2, North Channel; Zone 3, approaches to the North Channel; and Zone 4, Atlantic. All jellyfish encountered during stranding surveys were identified to species level (where possible) and tallied except in the case of mass strandings, when jellyfish were estimated to the nearest hundred. Subsequently, all stranding data were standardised to densities (ind. $\mathrm{km}^{-1}$ of shoreline). Linear survey distance was determined by hand-held GPS ( $\pm 5 \mathrm{~m}$ ). Jellyfish species were segregated into 2 groups for detailed analysis according to their life history. The scyphozoan Pelagia noctiluca differs from other members of this class by not having a metagenic life history (Russell 1970), and the hydrozoan Velella velella, although metagenic, completes both of its life stages in the pelagic environment ('oceanic'; Purcell et al. 2012). The remaining taxa (including the hydrozoan Aequorea sp.) encountered in the surveys all have a benthic polyp or hydroid stage that require substrate for settlement ('coastal').

\section{Statistical analysis}

Variation in species composition of shoreline strandings was examined using permutational ANOVA (PERMANOVA, PRIMER 6.1.12; Clarke \& Gorley 2006), a non-parametric probability based analogue of analysis of variance between 2 or more groups based on a distance measure (Anderson 2001, McArdle \& Anderson 2001). A 0-adjusted Bray-Curtis similarity matrix was created from the $\log (x+1)$ transformed density data. A 2-factor PERMANOVA with 9999 permutations (Anderson 2001, Anderson et al. 2008) was performed on the species composition similarity matrix to reveal consistency of stranded jellyfish assemblages between (1) survey year (3 levels, random) and zone (4 levels, nested in year, random) and their interaction (model term: year $x$ zone[year]), and (2) months (year $\times$ month[year]), year (3 levels, random) and month (12 levels, nested in year, random), both within and between years. To identify spatial patterns of strandings, analyses were performed on all species and separately on both coastal and oceanic species.

Circular statistics were used to test whether observed densities of each species were correlated with survey month and location (survey beach) in Oriana v4 (Kovach Computing Services). Survey dates were ranked into months of the year and assigned angles by the program, i.e. $360^{\circ}$ divided into $12 \mathrm{mo}$, each sector being $30^{\circ}$ wide with the month at the midpoint, e.g. January at $15^{\circ}$ (see Kovach 2011). Beach locations were converted into vectors from a point approximately in the centre of the north of Ireland and assigned degrees accordingly. The null hypothesis that the locations of stranding events would be distributed uniformly throughout the year was tested using Rayleigh's uniformity test (Batschelet 1981, Fisher 1993). A test of uniformity of distribution was not carried out for the stranding location data, as $143^{\circ}$ $\left(130^{\circ}\right.$ to $\left.273^{\circ}\right)$ incorporated landmass and was redundant in the analysis. Circular-linear correlations were then used to test the relationship between (1) month and density and (2) location and density for the different species of jellyfish stranded. Circularlinear correlation coefficients range from 0 to 1 and describe the association of the circular variable (loca- 

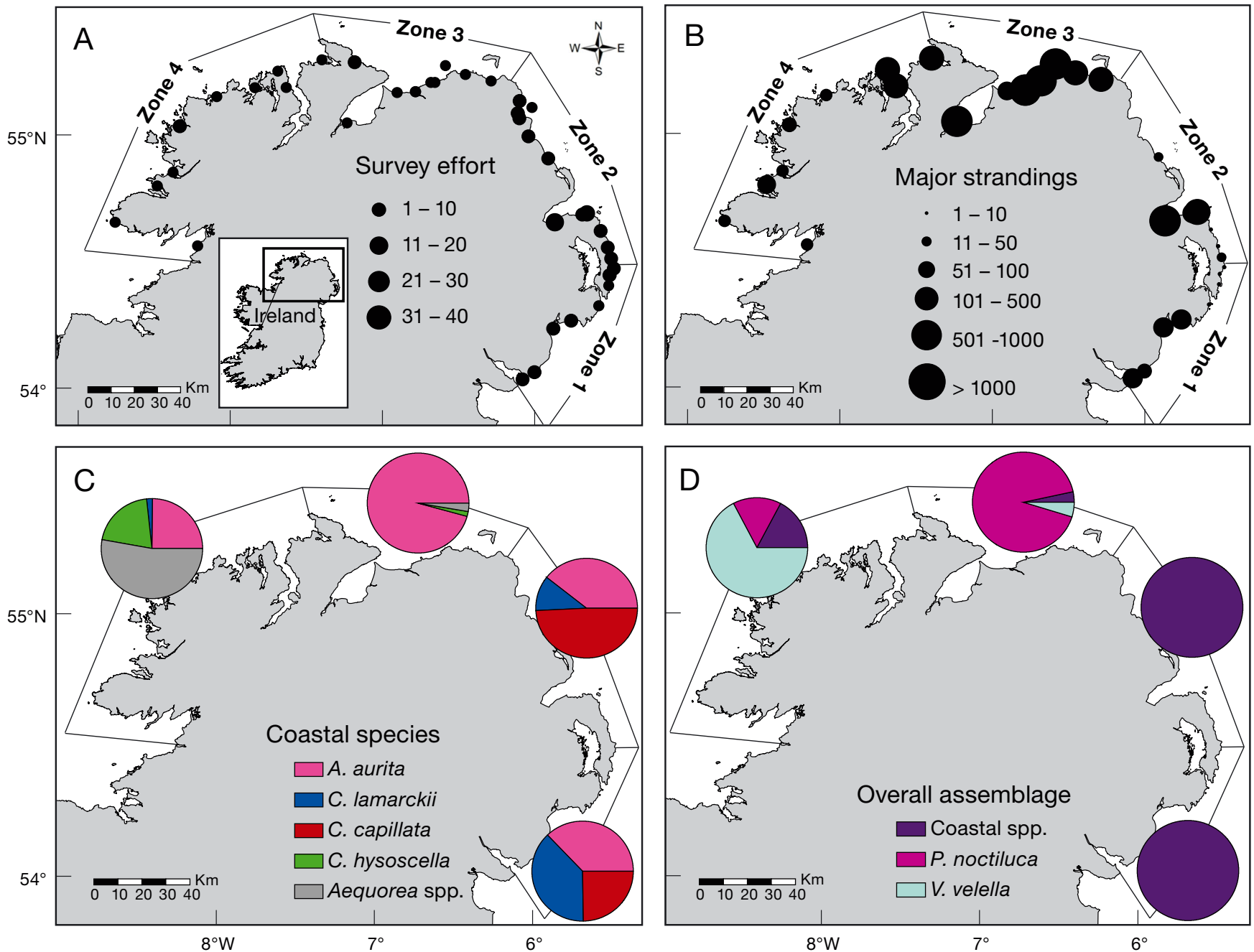

Fig. 1. (A) Survey effort (number of times a beach was surveyed between 2009 and 2011) and the 4 zones (each consisting of 10 beaches) classified according to their proximate body of water: Zone 1, Irish Sea; Zone 2, North Channel; Zone 3, approaches to the North Channel; Zone 4, Atlantic. (B) Areas most vulnerable to major stranding events, with Zones 3 and 4 most affected by Pelagia noctiluca, and Zones 1 and 2 by Cyanea capillata. (C) Numerical contribution of different coastal jellyfish species from 2009 to 2011 (oceanic jellyfish excluded from the total number of stranded individuals). (D) Proportional contribution of all jellyfish species to the total number of stranded individuals, highlighting the predominance of $P$. noctiluca along the coastline facing the Atlantic (Zones 3 and 4). All species names are given in Table 1

tion or month) with a linear quantity (densities of jellyfish) assigned to it; the larger the correlation coefficient, the stronger the relationship between month/ location and densities of jellyfish.

\section{RESULTS}

Between 2009 and 2011, a total of 6 species and 1 additional genus of gelatinous zooplankton (Phylum Cnidaria) were encountered and identified (described as density of stranded jellyfish per $\mathrm{km}$ of beach). These included 5 scyphozoan species (Order
Semaeostomeae): Aurelia aurita (Linnaeus, 1758) (range 0-1250 ind. $\mathrm{km}^{-1}$ ), Cyanea lamarckii (Péron \& Lesueur 1810) (0-505 ind. $\left.\mathrm{km}^{-1}\right), C$. capillata (Linnaeus 1758) (0-548 ind. $\left.\mathrm{km}^{-1}\right)$, Chrysaora hysoscella (Linnaeus 1758) (0-34 ind. $\mathrm{km}^{-1}$ ) and Pelagia noctiluca (Forsskål 1775) (0-25 000 ind. $\left.\mathrm{km}^{-1}\right)$; and hydrozoans (Order Leptothecata): Aequorea spp. (Péron \& Lesueur 1810) (0-89 ind. $\left.\mathrm{km}^{-1}\right)$ and (Order Anthoathecata): Velella velella (Linnaeus 1758) (0-1587 ind. $\mathrm{km}^{-1}$ ) (Table 1). Aequorea spp. were only identified to genus; 3 species inhabit UK/Irish waters, but they are not distinguishable once stranded and partially degraded. 
Table 1. Jellyfish strandings from 2009 to 2011 across the north of Ireland ( $\mathrm{N}=40$ beaches), showing total number of sites where the species were recorded, total number of individuals recorded, total number of stranding events recorded and the mean $\pm \mathrm{SD}$ of stranded individuals $\left(\mathrm{km}^{-1}\right)$

\begin{tabular}{|lcccc|}
\hline Species & $\begin{array}{c}\text { No. of } \\
\text { sites }\end{array}$ & $\begin{array}{c}\text { No. of } \\
\text { individuals }\end{array}$ & $\begin{array}{c}\text { No. of } \\
\text { events }\end{array}$ & $\begin{array}{c}\text { No. of } \\
\text { stranded } \\
\text { individuals }\end{array}$ \\
\hline Coastal & & & & \\
Aurelia aurita & 19 & 3810 & 34 & $112 \pm 297$ \\
Cyanea lamarckii & 11 & 817 & 16 & $51 \pm 141$ \\
Cyanea capillata & 16 & 2401 & 50 & $48 \pm 112$ \\
Chrysaora hysoscella & 14 & 169 & 30 & $6 \pm 8$ \\
Aequorea spp. & 12 & 375 & 24 & $16 \pm 21$ \\
Oceanic & & & & \\
Pelagia noctiluca & 17 & 46830 & 26 & $1801 \pm 4989$ \\
Velella velella & 10 & 4740 & 12 & $395 \pm 444$ \\
\hline
\end{tabular}

\section{Spatial distribution of gelatinous assemblages}

Strandings of Aurelia aurita and Cyanea lamarckii occurred throughout the entire survey area (Zones 1 to 4). C. capillata appeared to be restricted to stranding on the Irish Sea beaches (Zone 1) and the southern part of the North Channel (Zone 2), and did not appear on shores beyond this area. The remaining coastal species (Chrysaora hysoscella and Aequorea spp.) occurred in small numbers on beaches facing the North Channel and approaches to the North Channel (Zones 2 and 3; maximum 22 and 40 ind. $\mathrm{km}^{-1}$, respectively) but were found in slightly greater numbers (maximum 34 and 89 ind. $\mathrm{km}^{-1}$ ) on beaches of the northwest coast facing the open NEA (Zone 4). Pelagia noctiluca and Velella velella are oceanic species without a benthic stage and stranded in high numbers on beaches fronting the Atlantic Ocean mainly on approaches to the North Channel (Zone 3; maximum 25000 and 1587 ind. $\mathrm{km}^{-1}$, respectively) and were present in smaller numbers on the Atlanticfacing beaches in Zone 4 (maximum 246 and 769 ind. $\mathrm{km}^{-1}$; Fig. 1).

The species assemblage of the stranded jellyfish encountered during the survey (i.e. the relative numerical contribution of each species) differed between the 4 zones (zone: pseudo- $F_{9,563}=6.379, p=0.0001$; Fig. 1). Differences also emerged when separate analyses were conducted for coastal and oceanic species (coastal: pseudo- $F_{9,563}=5.345, \mathrm{p}=0.0001$; oceanic: pseudo- $\left.F_{9,563}=9.624, \mathrm{p}=0.0001\right)$. PERMANOVA also revealed a consistent year/zone relationship with no significant variation in assemblage in zones between the survey years (all species: pseudo- $F_{9,563}=1.441, \mathrm{p}=$ 0.176 ; coastal: pseudo- $F_{9,563}=1.196, p=0.319$; oceanic: pseudo- $F_{9,563}=1.629, \mathrm{p}=0.212$ ). Circular statistics provided information on spatial patterns in species distribution. A weak circular-linear correlation was found for all species between location and stranding density (Table 2), with the exception of Aurelia aurita and Cyanea lamarckii $(\mathrm{r}=0.042, \mathrm{p}=0.369 ; \mathrm{r}=$ $0.062, p=0.113$, respectively). Care must be taken with the interpretation of these significant relationships, given that the correlations are very weak, and in part reflect the unavoidable replication of survey effort. However, the analysis remains informative given that significant relationships only emerged for species with spatially discrete distributions (e.g. Pelagia noctiluca and Aequorea sp. along the north coast), but not for species with cosmopolitan distributions (A. aurita and C. lamarckii).

\section{Seasonality of strandings}

Nested 2-way PERMANOVA showed that the jellyfish community differed in structure between months, indicating that different species stranded in different months (pseudo- $F_{20,563}=6.709, \mathrm{p}=0.0001$ ): this pattern was consistent between survey years (pseudo$F_{2,563}=1.093, \mathrm{p}=0.352$ ) (Figs. $2 \& 3$ ). When analysed as separate groups, there was again no difference between years within each group (coastal: pseudo$F_{2,563}=1.23, \mathrm{p}=0.322$; oceanic: pseudo- $F_{2,563}=1.521$, $\mathrm{p}=0.233$ ), but there was variation in the intra-annual strandings of the species within groups (coastal: pseudo- $F_{20,563}=7.721, p=0.0001$; oceanic: pseudo$F_{20,563}=3.286, \mathrm{p}=0.0001$; Fig. 4). The seasonality of the strandings of the 2 groups is illustrated in Figs. 2 $\& 4$ and shows cessation of strandings of coastal species (with the exception of Aequorea spp.) around September and an increase of strandings of the

Table 2. Circular-linear correlation between jellyfish densities and location; $\mathrm{n}=564$ for all species

\begin{tabular}{|lcr|}
\hline Species & $\mathrm{r}$ & $\mathrm{p}$ \\
\hline Coastal & & \\
Aurelia aurita & 0.042 & 0.369 \\
Cyanea lamarckii & 0.062 & 0.113 \\
Cyanea capillata & 0.111 & $<0.001$ \\
Chrysaora hysoscella & 0.176 & $<0.001$ \\
Aequorea spp. & 0.183 & $<0.001$ \\
Oceanic & & \\
Pelagia noctiluca & 0.084 & 0.019 \\
Velella velella & 0.105 & 0.002 \\
\hline
\end{tabular}




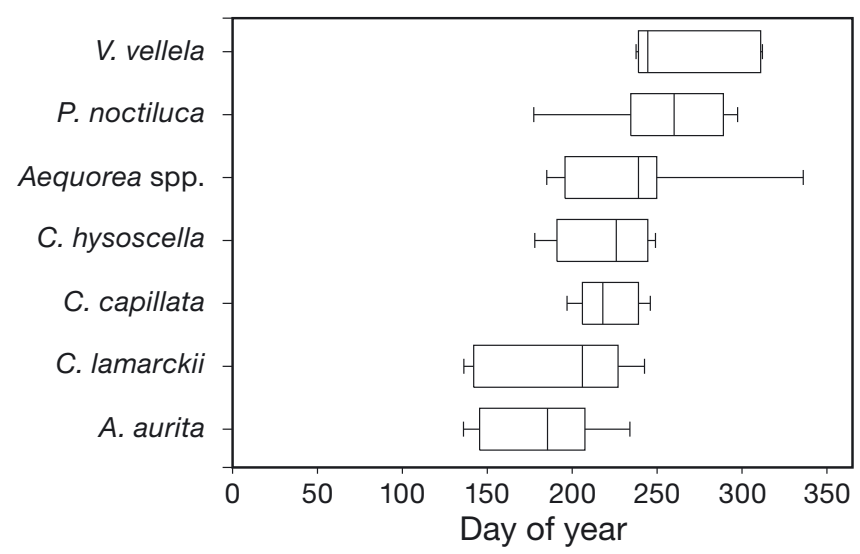

Fig. 2. Median stranding date ( \pm 5th and 95th percentiles), illustrating the seasonality of all stranded jellyfish species encountered during 2009 to 2011 (all zones combined). Boxes represent first and third quartiles (50\% of all stranding events), with $90 \%$ of all stranding events bounded by the error bars. All species names are given in Table 1

oceanic species in the previous month. As our analysis showed no effect of survey year on stranding data, all years were pooled subsequently for circular statistical analysis. Rayleigh's test of uniformity was significant for all species $(\mathrm{p}<0.001)$, showing that stranding densities of each species were anisotropic and therefore not randomly distributed throughout the year. There was a circular-linear correlation for all species between month and stranding density (Table 3), except Cyanea lamarckii $(\mathrm{r}=0.072, \mathrm{p}=$ 0.054), which was on the threshold of conventional statistical significance. This lack of a strong correlation may reflect a combination of the small number of both stranding events and total number of individuals observed (see Table 1).

\section{DISCUSSION}

\section{Spatial and temporal patterns of jellyfish stranding events}

The identification of temporal and spatial patterns in jellyfish occurrences is vital if we are to accurately predict the likelihood of interactions between jellyfish and aquaculture facilities, with the potential to distinguish likely hot-spots and hazardous times of year (Nickell et al. 2010). Although accurate estimates of the distribution of gelatinous species in any coastal region are difficult to obtain (Colombo et al. 2003, Callaway et al. 2012), distinct spatial and temporal patterns emerged from our shoreline surveys
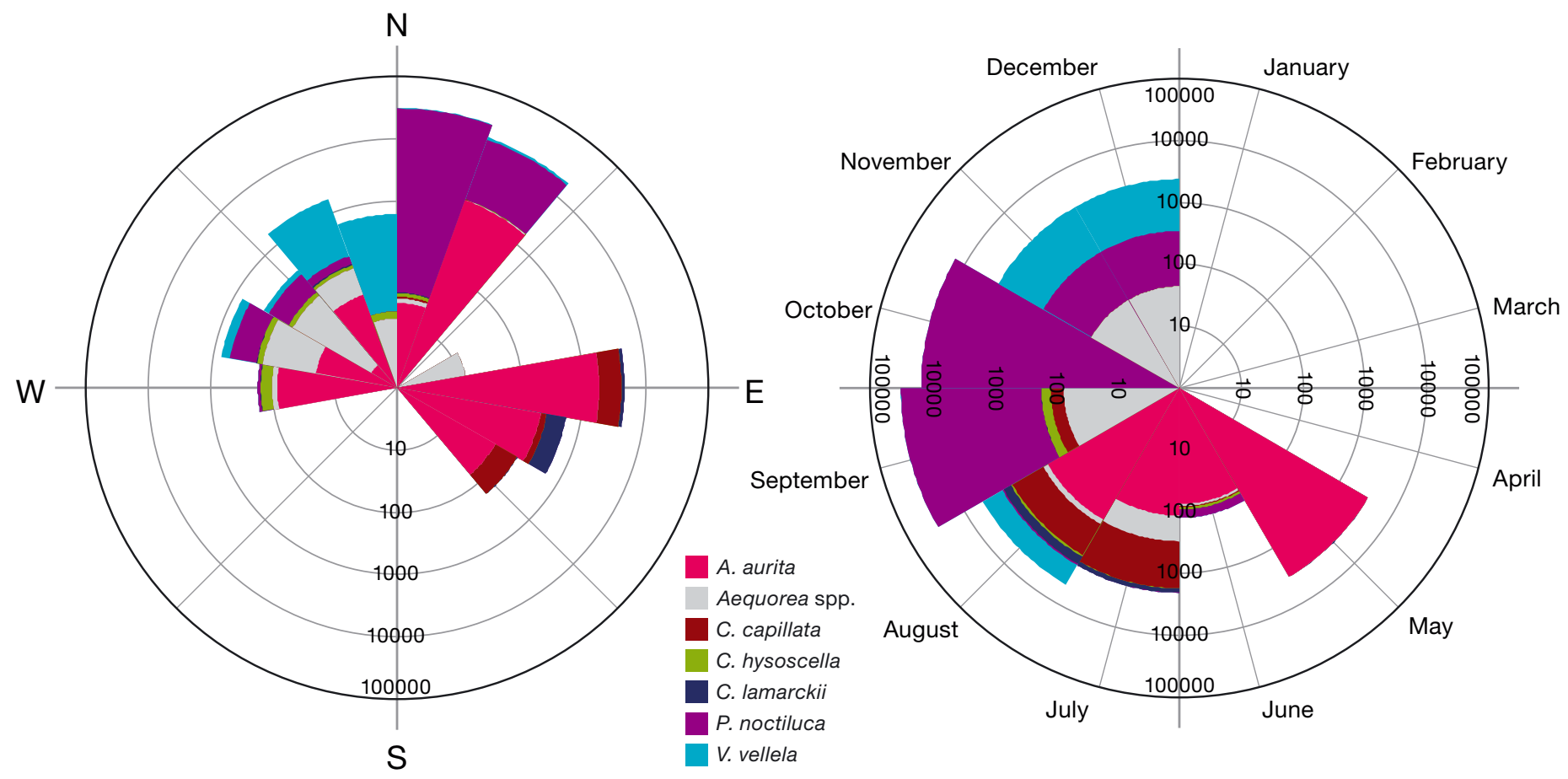

Fig. 3. Relative proportions of all jellyfish species by location around the coast of the north of Ireland in each month. The circular axis represents location (left) and month (right), and position on the grid (stacked wedge) indicates relative proportions of all stranded jellyfish. In particular, these plots highlight the ubiquity of Aurelia aurita and the predominance of $C y a n e a$ capillata and Pelagia noctiluca at locations proximate to the Irish Sea and Atlantic, respectively. Note the use of $\log _{10}$ scales. All species names are given in Table 1 

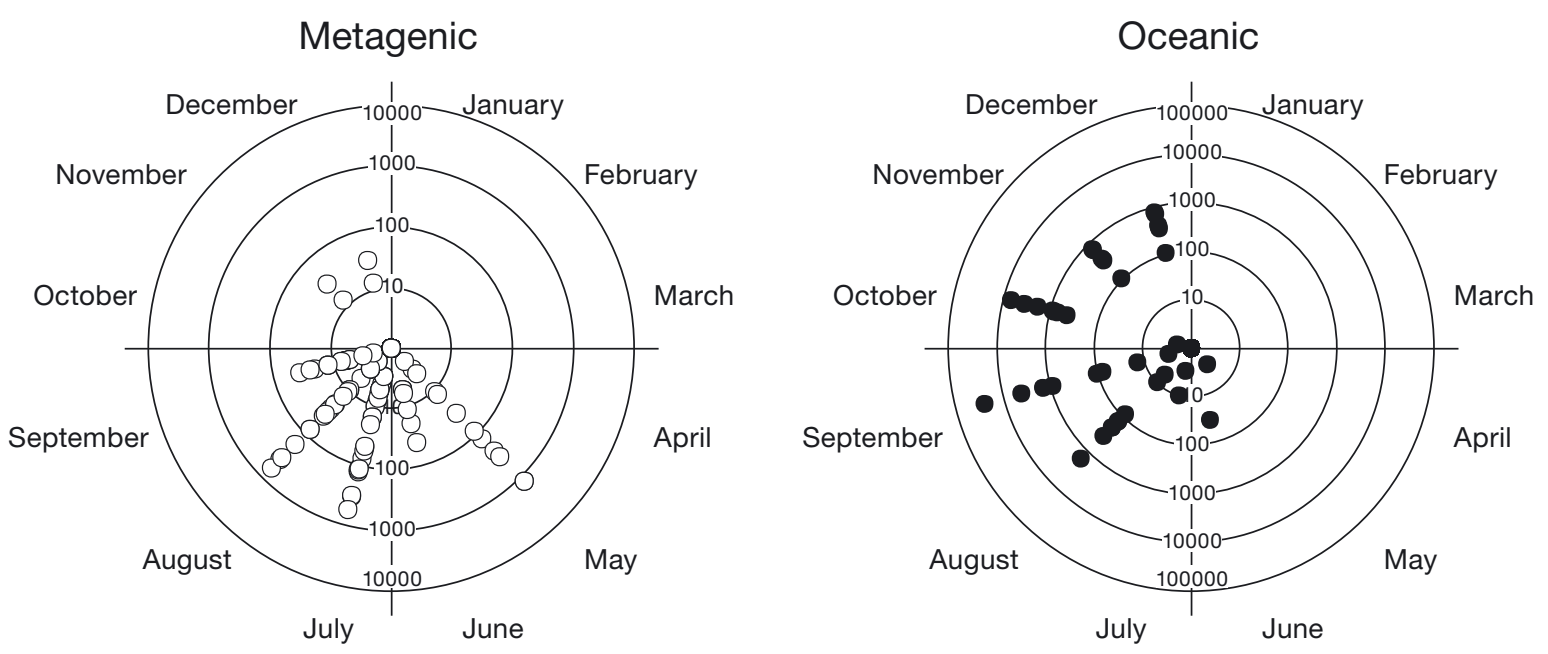

Fig. 4. Circular-linear plots showing the number of coastal (left) and oceanic (right) jellyfish stranded on all beaches throughout the year. The circular axis represents month, and position on the grid indicates number of jellyfish observed. Points on the plot represent the number of stranded jellyfish recorded from 1 beach survey. These plots indicate how coastal jellyfish species consistently strand between May and September, whilst the oceanic species strand from August to December. Note the use of $\log _{10}$ scales and differences in axis scales

Table 3. Circular-linear correlation between jellyfish densities and month; $\mathrm{n}=566$ for all species

\begin{tabular}{|lcr|}
\hline Species & $\mathrm{r}$ & \multicolumn{1}{c|}{$\mathrm{p}$} \\
\hline Coastal & & \\
Aurelia aurita & 0.117 & $<0.001$ \\
Cyanea lamarckii & 0.072 & 0.054 \\
Cyanea capillata & 0.146 & $<0.001$ \\
Chrysaora hysoscella & 0.152 & $<0.001$ \\
Aequorea spp. & 0.103 & 0.002 \\
Oceanic & & \\
Pelagia noctiluca & 0.092 & 0.008 \\
Velella velella & 0.098 & 0.004 \\
\hline
\end{tabular}

around the north of Ireland, providing key information for the future development of coastal activities, including aquaculture.

An important finding to emerge from the shoreline survey programme was that oceanic species only stranded on beaches directly exposed to the open Atlantic (i.e. Zones 3 and 4, Fig. 1). This pattern corroborates the suggestion by Doyle et al. (2008) that the large aggregations of Pelagia noctiluca that infested the salmon farms in County Antrim in 2007 did not arise in situ nor move up through the Irish Sea (as widely reported in the media), but were driven shoreward from offshore locations to the north of Ireland and west of Scotland. The key point here is that large aggregations of $P$. noctiluca remain a threat to the aquaculture industry around the north of Ireland (and by logical extension to the west of Scotland) and that the events of 2007 were not an isolated incident.
With respect to the timing of stranding events, Pelagia noctiluca was distinguished further from the other scyphozoan species in our study by stranding mostly during the autumn (September to November; Figs. 2 to 4). This pattern of autumnal stranding of $P$. noctiluca is in contrast to strandings of the same species in the Mediterranean Sea where they will strand en masse on beaches during the summer months (Mariottini et al. 2008). In Irish/UK waters, P. noctiluca occurred every year during the survey. Using a 200 yr time series, Goy et al. (1989) suggested that Mediterranean populations of $P$. noctiluca appeared to fluctuate between high and low abundances (see also Condon et al. 2013 and references therein). As there was a noticeable decline in numbers of $P$. noctiluca in our survey area from 2009 onwards, it is possible that numbers are highly variable in the NEA, although such conclusions cannot be drawn from the 2 yr (i.e. July 2009 to August 2011) of data presented here. Alternatively, it is possible that inter-annual differences in the magnitude of $P$. noctiluca stranding events reflect shifts in weather patterns (rather than population size) which serve to drive aggregations shoreward in particular years (Zavodnik 1987, Graham et al. 2001). Velella velella, a floating athecate hydrozoan polyp, displayed autumn/winter stranding similar to $P$. noctiluca, which may be evidence to suggest that meteorological conditions could be an important factor in advecting oceanic species into inshore waters. The stranding of oceanic species may show a proportion of a (or whole) population being driven shoreward en masse leading to an isolated 
(albeit major) stranding event. Indeed, oceanic species stranded typically in great numbers $(P$. noctiluca, max. 25000 ind. $\mathrm{km}^{-1}$ ), often an order of magnitude greater than coastal species (Aurelia aurita, max. 1250 ind. $\mathrm{km}^{-1}$ ).

Coastal scyphozoan jellyfish stranded over a protracted time frame (May to September), with numbers decreasing from August onwards before a complete disappearance in October. Although variable for the entire assemblage, there was some degree of intraspecies predictability (i.e. each species had a relatively consistent stranding period). There was also a distinct succession in the timing of stranding events starting with Aurelia aurita in May, Cyanea lamarckii in June and $C$. capillata in July. It is interesting to note that this pattern of disappearance from the water column reflects the pattern by which they are first observed at the start of the summer in Strangford Lough, Northern Ireland (N. Fleming pers. obs.), the German Bight (Dittrich 1988) and Gullmar Fjord, Sweden (Gröndahl 1988), although further work is required to link the timing of strobilation events at the seabed to the senescence and eventual stranding of medusae (Houghton et al. 2007).

The spatial patterns of coastal jellyfish strandings were consistent with our hypothesis that species with life cycles involving strobilation from benthic polyps (or hydroids) would display a marked consistency over time. The assemblages of coastal species were, in general, different in each 'zone' and consistent from year to year, suggesting stable patterns of distribution across the north of Ireland during the survey period (Fig. 1). The perennial nature of benthic polyp and hydroid colonies (Purcell et al. 2009, Lucas et al. 2012) would ensure an annual supply of ephyrae and subsequently medusae to the water column. Longstanding polyp (and hydroid) colonies may be supplemented each year following the sexual reproduction of the medusae (Houghton et al. 2007), leading to a positive feedback loop in terms of distribution (i.e. medusae will overlap spatially with the polyps that produce them, with a new generation of polyps arising in the same location (and beyond) from the sexual reproduction of medusae). These defined jellyfish distributions agree with the findings of Sparks et al. (2001), Houghton et al. (2007) and Doyle et al. (2007), who noted that the occurrence of certain species of jellyfish in particular areas may not be as passive or random as once thought. In some cases there were distinct areas where different species and groups of species with different life histories repeatedly occurred and others from which they were mostly or entirely absent. Viewed in conjunction with oceanic jellyfish strandings, this temporal and spatial consistency for coastal jellyfish species highlights that the threat to aquaculture facilities is two-fold: (1) predictable localised blooms of coastal jellyfish that most likely arise in situ (albeit with marked interannual abundance) and (2) episodic incursions of oceanic jellyfish that form far out at sea and are driven shoreward by meteorological conditions in tremendous numbers (e.g. Zavodnik 1987, Graham et al. 2001).

\section{Shoreline surveys as a monitoring tool}

As spatial patterns of stranding events around the north of Ireland appeared to be consistent year to year for coastal jellyfish, shoreline surveys may allow an assessment of which areas are most at risk from the more harmful of these species (Baxter et al. 2011a,b). Cyanea capillata, for example, is known for its gill cell toxicity (Helmholz et al. 2010) and its propensity for causing damage to farmed finfish species (Bruno \& Ellis 1985, Rodger et al. 2011). Although this species strands in varying magnitudes throughout the summer months, it displayed a defined spatial distribution and was absent from a large part of the survey area (Fig. 1). Surveys to detect coastal species such as C. capillata do not need to be conducted continuously; once a species has been identified in an area and its distribution confirmed, it is likely to persist in the same over time. However, confirming long-term distribution of oceanic species still remains a problem, as the mechanisms for their advection into coastal waters in Irish/UK waters is not fully understood.

There may also be a proportion of the year that is without coastal medusae, as they have a defined residence time in the water column (e.g. Gröndahl 1988, Lucas 2001). It is possible that during these months there will be ephyrae (early medusal stage) of coastal jellyfish species in the water column. The potential for ephyrae as gill pathogens cannot be discounted, and they should be considered during in situ monitoring efforts around mariculture facilities (Nickell et al. 2010, Baxter et al. 2011a). Another technique that is gaining momentum is the use of environmental DNA sequencing (e.g. Bayha \& Graham 2009, Thomsen et al. 2012) which can detect micro- and mesoplanktonic species (including jellyfish ephyrae) present in the water column without the need for visual identification. In situ monitoring is a powerful tool which gives a snapshot of what is in the water column at a particular time; however, it does not give a 
geographical context for the threats that are present outside of the immediate area at that time. Aerial surveys (Purcell et al. 2000, Graham et al. 2003, Houghton et al. 2006, Nickell et al. 2010) and remote sensing (Nickell et al. 2010) have been tested successfully for large-scale jellyfish surveys but can be expensive and weather dependent. Shoreline surveys are not the complete solution but they are easily repeatable, relatively inexpensive and can provide a broad backdrop to in situ monitoring techniques. They can also help with the assessment of potential threats when considering areas in which to site future aquaculture facilities.

Acknowledgements. This study was supported by a Department of Education and Learning (DEL) PhD studentship awarded to N.E.C.F. by the Northern Ireland Assembly and internal funds at Queen's University Belfast. Thanks to D. Griffin, C. Webster, S. Guist, T. Lilley and D. Doyle for help with beach surveys. We also thank the 3 anonymous reviewers whose comments helped improve the manuscript.

\section{LITERATURE CITED}

Anderson MJ (2001) A new method for non-parametric multivariate analysis of variance. Austral Ecol 26:32-46

Anderson MJ, Gorley RN, Clarke KR (2008) PERMANOVA+ for PRIMER: guide to software and statistical methods. PRIMER-E, Plymouth

Arai MN (1997) A functional biology of Scyphozoa. Chapman \& Hall, London

Bastian T, Stokes D, Kelleher JE, Hays GC, Davenport J, Doyle TK (2011) Fisheries bycatch data provide insights into the distribution of the mauve stinger (Pelagia noctiluca) around Ireland. ICES J Mar Sci 68:436-443

Batschelet E (1981) Circular statistics in biology. Academic Press, London

Baxter EJ, Rodger HD, McAllen R, Doyle TK (2011a) Gill disorders in marine-farmed salmon: investigating the role of hydrozoan jellyfish. Aquacult Environ Interact 1:245-257

Baxter EJ, Sturt MM, Ruane N, Doyle TK, McAllen R, Harman L, Rodger HD (2011b) Gill damage to Atlantic salmon (Salmo salar) caused by the common jellyfish (Aurelia aurita) under experimental challenge. PLoS ONE 6:e18529

Bayha KM, Graham WM (2009) A new Taqman $\odot$ PCRbased method for the detection and identification of scyphozoan jellyfish polyps. Hydrobiologia 616:217-228

Bruno DW, Ellis AE (1985) Mortalities in farmed Atlantic salmon associated with the jellyfish Phialella quadrata. Bull Eur Assoc Fish Pathol 5:64-65

Callaway R, Shinn AP, Grenfell SE, Bron JE and others (2012) Review of climate change impacts on marine aquaculture in the UK and Ireland. Aquat Conserv 22:389-421

CIESM (Commission Internationale pour l'Exploration Scientifique de la mer Mediterranée (2001) Gelatinous zooplankton outbreaks: theory and practice. CIESM Workshop Series 14. CIESM, Monaco

Clarke KR, Gorley RN (2006) PRIMER v6: user manual/tutorial. PRIMER-E, Plymouth
Colin SP, Kremer P (2002) Population maintenance of the scyphozoan Cyanea sp. settled planulae and the distribution of medusae in the Niantic River, Connecticut, USA. Estuaries 25:70-75

> Colombo GA, Mianzan H, Madirolas A (2003) Acoustic characterization of gelatinous-plankton aggregations: four case studies from the Argentine continental shelf. ICES J Mar Sci 60:650-657

> Condon RH, Graham WM, Duarte CM, Pitt KA and others (2012) Questioning the rise of gelatinous zooplankton in the world's oceans. Bioscience 62:160-169

Condon RH, Duarte CM, Pitt KA, Robinson KL and others (2013) Recurrent jellyfish blooms are a consequence of global oscillations. Proc Natl Acad Sci USA 110: 1000-1005

Cronin M, Cusack C, Geoghegan F, Jackson D and others (2004) Salmon mortalities at Inver Bay and McSwyne's Bay finfish farms, County Donegal, Ireland, during 2003. Marine Environment and Health Series No.15. Marine Institute, Galway

Dittrich B (1988) Studies on the life cycle and reproduction of the parasitic amphipod Hyperia galba in the North Sea. Helgol Meeresunters 42:79-98

Doyle TK, Houghton JDR, Buckley SM, Hays GC, Davenport J (2007) The broad-scale distribution of five jellyfish species across a temperate coastal environment. Hydrobiologia 579:29-39

> Doyle TK, De Haas H, Cotton D, Dorshell B and others (2008) Widespread occurrence of the jellyfish Pelagia noctiluca in Irish coastal and shelf waters. J Plankton Res 30:963-968

FAO (Food and Agriculture Organization of the United Nations) (2012) The state of world fisheries and aquaculture 2012. FAO, Rome

Ferraris M, Berline L, Lombard F, Guidi L and others (2012) Distribution of Pelagia noctiluca (Cnidaria, Scyphozoa) in the Ligurian Sea (NW Mediterranean Sea). J Plankton Res 34:874-885

Fisher NI (1993) Statistical analysis of circular data. Cambridge University Press, Cambridge

Goy J, Morand P, Etienne M (1989) Long-term fluctuations of Pelagia noctiluca (Cnidaria, Scyphomedusa) in the western Mediterranean Sea: prediction by climatic variables. Deep-Sea Res 36:269-279

> Graham WM, Pagès F, Hamner WH (2001) A physical context for gelatinous zooplankton aggregations: a review. Hydrobiologia 451:199-212

- Graham WM, Martin DL, Felder DL, Asper VL, Perry HM (2003) Ecological and economic implications of a tropical jellyfish invader in the Gulf of Mexico. Biol Invasions 5: 53-69

Gröndahl F (1988) A comparative ecological study on the scyphozoans Aurelia aurita, Cyanea capillata and C. lamarckii in the Gullmar Fjord, western Sweden, 1982 to 1986. Mar Biol 97:541-550

> Helmholz H, Johnston BD, Ruhnau C, Prange A (2010) Gill cell toxicity of northern boreal scyphomedusae Cyanea capillata and Aurelia aurita measured by an in vitro cell assay. Hydrobiologia 645:223-234

> Houghton JDR, Doyle TK, Davenport J, Hays GC (2006) Developing a simple, rapid method for identifying and monitoring jellyfish aggregations from the air. Mar Ecol Prog Ser 314:159-170

Houghton JDR, Doyle TK, Davenport J, Lilley MKS, Wilson RP, Hays GC (2007) Stranding events provide indirect 
insights into the seasonality and persistence of jellyfish medusae (Cnidaria: Scyphozoa). Hydrobiologia 589:1-13

Kovach WL (2011) Oriana: Circular statistics for Windows, ver. 4. Kovach Computing Services, Pentraeth

Lee PLM, Dawson MN, Neill SP, Robins PE, Houghton JDR, Doyle TK, Hays GC (2013) Identification of genetically and oceanographically distinct blooms of jellyfish. J R Soc Interface 10:20120920, doi.org/10.1098/rsif.2012.0920

Licandro P, Conway DVP, Daly Yahia MN, Fernandez de Puelles ML and others (2010) A blooming jellyfish in the northeast Atlantic and Mediterranean. Biol Lett 6: 688-691

Lucas CH (2001) Reproduction and life history strategies of the common jellyfish, Aurelia aurita, in relation to its ambient environment. Hydrobiologia 451:229-246

Lucas CH, Graham WM, Widmer C (2012) Jellyfish life histories: role of polyps in forming and maintaining scyphomedusa populations. Adv Mar Biol 63:133-196

Mariottini GL, Giacco E, Pane L (2008) The mauve stinger Pelagia noctiluca (Forsskål, 1775). Distribution, ecology, toxicity and epidemiology of stings: a review. Mar Drugs 6:496-513

McArdle BH, Anderson MJ (2001) Fitting multivariate models to community data: a comment on distance-based redundancy analysis. Ecology 82:290-297

Nickell T, Davidson K, Fox C, Miller P, Hays G (2010) Developing the capacity to monitor the spatial and temporal distribution of jellyfish in western Scottish waters. The Crown Estate. Available at www.thecrownestate.co.uk

Purcell JE (2005) Climate effects on formation of jellyfish and ctenophore blooms: a review. J Mar Biol Assoc UK 85:461-476

$>$ Purcell JE (2009) Extension of methods for jellyfish and ctenophore trophic ecology to large-scale research. Hydrobiologia 616:23-50

Purcell JE, Brown ED, Stokesbury KDE, Haldorson LH, Shirley TC (2000) Aggregations of the jellyfish Aurelia

Editorial responsibility: Megan La Peyre,

Baton Rouge, Louisiana, USA labiata: abundance, distribution, association with age-0 walleye pollock, and behaviors promoting aggregation in Prince William Sound, Alaska, USA. Mar Ecol Prog Ser 195:145-158

$>$ Purcell JE, Hoover RA, Schwarck NT (2009) Interannual variation of strobilation by the scyphozoan Aurelia labiata in relation to polyp density, temperature, salinity, and light conditions in situ. Mar Ecol Prog Ser 375: 139-149

> Purcell JE, Clarkin E, Doyle TK (2012) Foods of Velella velella (Cnidaria: Hydrozoa) in algal rafts and its distribution in Irish seas. Hydrobiologia 690:47-55

Rodger HM, Henry L, Mitchell SO (2011) Non-infectious gill disorders of marine salmonid fish. Rev Fish Biol Fish 21: 423-440

Rottini-Sandrini L, Stravisi F, Pieri G (1980) A recent shift in the wind distribution and the appearance of unusual planktonic organisms in the Gulf of Trieste. Boll Soc Adriat Sci 64:77-84

Russell FS (1967) On the occurrence of the scyphomedusan Pelagia noctiluca in the English Channel in 1966. J Mar Biol Assoc UK 47:363-366

Russell FS (1970) The medusae of the British Isles II. Cambridge University Press, Cambridge

> Sparks C, Buecher E, Brierley AS, Axelsen BE, Boyer H, Gibbons MJ (2001) Observations on the distribution and relative abundance of the scyphomedusan Chrysaora hysoscella (Linné, 1766) and the hydrozoan Aequorea aequorea (Forskål, 1775) in the northern Benguela ecosystem. Hydrobiologia 451:275-286

Thomsen PF, Kielgast J, Iversen LL, Møller PR, Rasmussen M, Willerslev E (2012) Detection of a diverse marine fish fauna using environmental DNA from seawater samples. PLoS ONE 7:e41732

- Zavodnik D (1987) Spatial aggregations of the swarming jellyfish Pelagia noctiluca (Scyphozoa). Mar Biol 94: 265-269

Submitted: February 21, 2013; Accepted: October 16, 2013 Proofs received from author(s): December 12, 2013 